\title{
Modulation of $\left[{ }^{3} \mathrm{H}\right]$-dopamine released by different frequencies of stimulation from rabbit retina
}

\author{
Margarita L. Dubocovich ${ }^{1} \&$ Julie G. Hensler \\ Department of Pharmacology, Northwestern University Medical School, 303 East Chicago Avenue, Chicago, \\ Illinois 60611 , U.S.A.
}

1 Rabbit retinal pieces were incubated with $\left[{ }^{3} \mathrm{H}\right]$-dopamine and superfused with Krebs solution. Calcium-dependent tritium release was elicited twice within each experiment by electrical field stimulation ( 360 pulses, $2 \mathrm{~ms}, 20 \mathrm{~mA}$ ) at frequencies of $1 \mathrm{~Hz}, 3 \mathrm{~Hz}$, and $6 \mathrm{~Hz}$. The evoked release of $\left[{ }^{3} \mathrm{H}\right]$-dopamine for the first period of stimulation $\left(\mathrm{S}_{1}\right)$ was $2.09 \pm 0.23 \%(n=5)$ at $1 \mathrm{~Hz}$ and was of similar magnitude at all other frequencies of stimulation employed.

2 The $\mathrm{D}_{2}$-dopamine receptor agonist, $\mathrm{LY} 171555$ (quinpirole $\mathrm{HCl} ; 0.01-1 \mu \mathrm{M}$ ) added to the superfusion medium before the second period of stimulation, inhibited the calcium-dependent release of $\left[{ }^{3} \mathrm{H}\right]$-dopamine in a concentration-dependent manner, and was more potent the lower the stimulation frequency. The isomer of quinpirole, LY $181990(0.01-1 \mu \mathrm{M})$ did not inhibit the stimulation-evoked overflow of tritium, regardless of concentration or stimulation frequency.

3 The stereoisomers of the $D_{2}$-dopamine receptor antagonist sulpiride $(0.01-3 \mu \mathrm{M})$ increased the calcium-dependent release of $\left[{ }^{3} \mathrm{H}\right]$-dopamine in a concentration-dependent manner, being more potent the higher the frequency of stimulation. S-sulpiride was more potent than R-sulpiride at all stimulation frequencies. The inhibitory effect of quinpirole was stereoselectively antagonized by sulpiride, but not by LY 181990 . The $\alpha$-adrenoceptor antagonist phentolamine $(1 \mu \mathrm{M})$ did not modify the quinpiroleinduced inhibition of $\left[{ }^{3} \mathrm{H}\right]$-dopamine release.

4 When the synaptic concentration of dopamine was increased by the presence of the dopamine uptake inhibitor nomifensine $(3 \mu \mathrm{M})$, the potency of the agonist quinpirole in inhibiting the release of $\left[{ }^{3} \mathrm{H}\right]$-dopamine elicited by field stimulation at $1 \mathrm{~Hz}$ ( 180 pulses) was decreased. In contrast, the potency of S-sulpiride in enhancing the evoked release of $\left[{ }^{3} \mathrm{H}\right]$-dopamine was increased when nomifensine was present in the superfusion medium.

5 Picomolar concentrations of the hormone melatonin $(0.1-10 \mathrm{nM})$ inhibited the calcium-dependent release of $\left[{ }^{3} \mathrm{H}\right]$-dopamine from rabbit retina with the same potency regardless of the frequency of stimulation applied $(1 \mathrm{~Hz}, 3 \mathrm{~Hz}$ or $6 \mathrm{~Hz})$.

6 The potency of $\mathrm{D}_{2}$-dopamine receptor agonists and antagonists in modifying $\left[{ }^{3} \mathrm{H}\right]$-dopamine release from rabbit retina appears to depend on the synaptic concentration of dopamine which is altered by the frequency of stimulation, and by the dopamine uptake inhibitor nomifensine. At lower synaptic concentrations of the transmitter dopamine the receptor agonist quinpirole was more potent in inhibiting $\left[{ }^{3} \mathrm{H}\right]$-dopamine release, while the receptor antagonist sulpiride was more potent in enhancing $\left[{ }^{3} \mathrm{H}\right]$-dopamine release the higher the synaptic concentration of dopamine. In contrast, the potency of melatonin in inhibiting $\left[{ }^{3} \mathrm{H}\right]$-dopamine release was not altered by the frequency of stimulation, or by frequency-dependent changes in the biophase concentration if the transmitter dopamine.

\section{Introduction}

In the mammalian retina, the activity of dopaminecontaining amacrine neurones is controlled through the activation of receptor sites for numerous

\footnotetext{
${ }^{1}$ Author for correspondence.
}

neurotransmitters and neuromodulators. In the rabbit retina, $D_{2}$-dopamine autoreceptors are involved in the modulation of the calcium-dependent release of $\left[{ }^{3} \mathrm{H}\right]-$ dopamine through a negative feedback mechanism mediated by the neurotransmitter itself (Dubocovich 
\& Weiner, 1981; 1985). The calcium-dependent release of $\left.{ }^{3} \mathrm{H}\right]$-dopamine from rabbit retina is also modulated through activation of inhibitory presynaptic $\alpha_{2}$-adrenoceptors (Dubocovich, 1984) and through the activation of stereoselective presynaptic opiate receptors (Dubocovich \& Weiner, 1983). The hormone melatonin is a potent inhibitor of the depolarizationevoked release of $\left[{ }^{3} \mathrm{H}\right]$-dopamine from rabbit retina (Dubocovich, 1983), activating a distinct receptor site pharmacologically different from monoamine receptor sites (Dubocovich, 1985).

The degree of modulation of transmitter release through autoreceptor activation has been shown to depend on the synaptic concentration of endogenous transmitter. The biophase concentration of transmitter and thus the potency of autoreceptor agonists and antagonists in modulating neurotransmitter release can be altered by neuronal uptake inhibitors, and by changing the frequency, intensity and duration of neuronal depolarization. Agonists more potently inhibit neurotransmitter release at lower biophase concentrations of transmitter, while antagonists more potently enhance neurotransmitter release the higher the synaptic concentration of transmitter. This has been demonstrated for $\alpha_{2}$-autoreceptor modulation of noradrenaline release from rabbit ear artery (Limberger \& Starke, 1984), rat and rabbit cortical slices (Bauman \& Koella, 1980; Reichenbacher et al., 1982; Heepe \& Starke, 1985), as well as for $D_{2-}$ and muscarinic autoreceptor modulation of dopamine and acetylcholine release from rabbit striatum, respectively (Cubeddu \& Hoffmann, 1983; James \& Cubeddu, 1984).

This study investigates the modulation of $\left[{ }^{3} \mathrm{H}\right]$ dopamine release from rabbit retina at different frequencies of field stimulation, through the activation of $\mathrm{D}_{2}$-dopamine autoreceptors and putative melatonin receptor sites. We have chosen to use in this study the stereoisomers of LY 141865 [trans-( \pm$)-4,4 a, 5,6,7$, 8a, 9-octahydro-5-propyl-2H-pyrazole $(3,4 \mathrm{~g})$ quinoline dihydrochloride], a selective $\mathrm{D}_{2}$-dopamine receptor agonist (Tsuruta et al., 1981; Stoof \& Kebabian, 1984) that has been shown to inhibit dopamine release from rabbit retina (Dubocovich \& Weiner, 1985) and from cat caudate (Lehmann et al., 1983). LY 171555 (quinpirole $\mathrm{HCl}$ ), the laevorotatory enantiomer, possesses $D_{2}$-dopamine receptor agonist activity whereas the dextrorotatory enantiomer of quinpirole, LY 181990 (a monohydrochloride salt) lacks $D_{2}$ dopamine receptor agonist activity (Titus $e$ t al., 1983; Wong et al., 1983; Fuller \& Hemrick-Luecke, 1985).

Our objective was to study in the retina the effect of the synaptic concentration of dopamine on the modulation of $\left[{ }^{3} \mathrm{H}\right]$-dopamine release through activation of $\mathrm{D}_{2}$-dopamine autoreceptors and melatonin receptor sites. The synaptic concentration of dopamine was modified by changes in the frequency of field stimulation or by the inhibition of neuronal uptake of dopamine. Under our experimental conditions, melatonin receptor sites were not activated by endogenous ligand as the levels of melatonin in the rabbit retina are low or undetectable during the day (Dubocovich et al., 1985). Some of these results have been reported to the British Pharmacological Society (Dubocovich \& Hensler, 1985a).

\section{Methods}

\section{Animals}

Albino rabbits $(2.5-3.5 \mathrm{~kg})$ maintained on a $14-10 \mathrm{~h}$ light-dark cycle were killed by decapitation during the light cycle. The eyes were enucleated and the cornea, lens and vitreous humor were carefully removed. The remaining eye cup was everted and placed in a vial containing $5 \mathrm{ml}$ of Krebs solution gassed with $95 \%$ $\mathrm{O}_{2}: 5 \% \mathrm{CO}_{2}$. The retina was detached by gentle shaking, during which the retina fragmented into several pieces.

\section{Superfusion experiments}

Retinal pieces were incubated for $20 \mathrm{~min}$ at $37^{\circ} \mathrm{C}$ in the presence of $0.1 \mu \mathrm{M}\left[{ }^{3} \mathrm{H}\right]$-dopamine (specific activity: 44.5 $\mathrm{Ci} \mathrm{mmol}^{-1}$, Amersham). The tissue from each retina was then washed in $5 \mathrm{ml}$ of Krebs solution, divided into four approximately equal portions and placed in four cylindrical plastic tubes, each with a thin nylon mesh on the bottom. Each of the eight plastic tubes containing pieces of rabbit retina were placed in glass superfusion chambers, between a pair of platinum electrodes $30 \mathrm{~mm}$ apart. The tissue was superfused, by means of a roller pump at a rate of $1 \mathrm{ml} \mathrm{min}^{-1}$, with $\mathrm{Krebs}$ solution prewarmed at $37^{\circ} \mathrm{C}$, until the spontaneous outflow of radioactivity had levelled off. The composition of the Krebs solution was (mM): $\mathrm{NaCl} 108, \quad \mathrm{KCl} 4.7$, glucose 11.1, $\mathrm{NaHCO}_{3}$ 25.0, $\mathrm{MgCl}_{2}$ 1.2, $\mathrm{NaH}_{2} \mathrm{PO}_{4}$ 1.0, $\mathrm{CaCl}_{2}$ 1.3, ascorbic acid 0.11 and disodium EDTA 0.004.

Tritium release was elicited by electrical field stimulation ( $20 \mathrm{~mA}, 2 \mathrm{~ms}$ duration) delivered by a Grass Stimulator model S44 at frequencies of $1 \mathrm{~Hz}$, $3 \mathrm{~Hz}$ or $6 \mathrm{~Hz}$. During stimulation, pulses were monitored on an oscilloscope. Two periods of field stimulation were applied in each experiment, at $60 \mathrm{~min}$ $\left(S_{1}\right)$ and at $100 \mathrm{~min}\left(\mathrm{~S}_{2}\right)$ after the beginning of superfusion. Samples of superfusate were collected by means of a fraction collector at $4 \mathrm{~min}$ intervals before, during and after each period of stimulation. The drugs were added to the perfusion medium either $40 \mathrm{~min}$ before $S_{1}$ or $20 \mathrm{~min}$ before $S_{2}$, and were present for the remainder of the experiment. At the end of the experiment, the retinal tissue contained in each cham- 
ber was solubilized in $0.5 \mathrm{ml}$ of TS-1 (Research Products International) and the tritium content was determined by liquid scintillation counting.

\section{Calculations}

The outflow of radioactivity in each sample was expressed as the percentage of the total tissue radioactivity present at the beginning of each sample collection: total tritium release per sample divided by total tritium present in the tissue, and multiplied by one hundred. The total radioactivity present in the tissue at the initiation of each sample collected was determined by adding the radioactivity present in the tissue at the end of the experiment to the radioactivity collected in each subsequent sample until the end of the sample collection. Throughout the text, 'spontaneous outflow of radioactivity' refers to the outflow of tritium released during the $4 \mathrm{~min}$ period preceding each period of field stimulation. The spontaneous outflow of radioactivity from the rabbit retina consists mainly of $\left[{ }^{3} \mathrm{H}\right]$-dopamine metabolites (see Dubocovich \& Weiner, 1981).

The total overflow of the transmitter is the percentage of total tissue radioactivity released above spontaneous levels, induced by the period of field stimulation (Dubocovich \& Weiner, 1981). Results are expressed as the ratio $\left(\mathbf{S}_{2} / \mathbf{S}_{1}\right)$ of the percentage of total tissue radioactivity released above spontaneous levels during the second $\left(S_{2}\right)$ and first $\left(S_{1}\right)$ periods of field stimulation within the same experiment. Throughout the text the 'overflow of transmitter' is also termed: 'calciumdependent release of $\left[{ }^{3} \mathrm{H}\right]$-dopamine' or 'evoked-release of $\left[{ }^{3} \mathrm{H}\right]$-dopamine'. Unpaired Student's $t$ test (two-tailed) was used for statistical comparisons.

\section{Drugs used}

Nomifensine maleate was donated by Hoechst-Roussel Pharmaceuticals, Inc. (Somerville, NJ); S- and Rsulpiride by Ravizza (Milan, Italy); LY 171555 and LY 181990 by the Lilly Laboratories (Indianapolis, IN); clonidine $\mathrm{HCl}$ by Boehringer Ingelheim Ltd. (Ridgefield, CT); phentolamine $\mathrm{HCl}$ by Ciba-Geigy (Summit, NJ). Yohimbine $\mathrm{HCl}$ was purchased from Aldrich (Milwaukee, WI). Melatonin was purchased from Sigma Chemical Company (St Louis, MO).

\section{Results \\ Calcium-dependent release of $\left[{ }^{3} \mathrm{H}\right]$-dopamine elicited at different frequencies of field stimulation}

The spontaneous outflow of radioactivity from rabbit retina pieces, previously labelled in vitro with $\left[{ }^{3} \mathrm{H}\right]-$ dopamine, during the 4 min period preceding the first period of field stimulation $\left(\mathrm{Sp}_{1}\right)$ for controls was $0.86 \pm 0.04 \%(n=15)$. The release of $\left[{ }^{3} \mathrm{H}\right]$-dopamine was elicited by electrical field stimulation at different frequencies $(1 \mathrm{~Hz}, 3 \mathrm{~Hz}$ or $6 \mathrm{~Hz})$, with the number of pulses kept constant. The percentage total tissue radioactivity released above spontaneous levels by the first $\left(S_{1}\right)$ period of field stimulation ( 360 pulses, $20 \mathrm{~mA}$, $2 \mathrm{~ms})$ was $2.09 \pm 0.23 \%(n=5)$ at a stimulation frequency of $1 \mathrm{~Hz}, 2.63 \pm 0.29 \%(n=6)$ at $3 \mathrm{~Hz}$, and $2.71 \pm 0.40 \%(n=4)$ at $6 \mathrm{~Hz}$ (Table 1). The evoked release of $\left[{ }^{3} \mathrm{H}\right]$-dopamine did not increase significantly with increasing stimulation frequency (Table 1). The ratio of the percentage of total tissue radioactivity released by the second period of stimulation to that

Table 1 Calcium-dependent release of $\left[{ }^{3} \mathrm{H}\right]$-dopamine from rabbit retina at different frequencies of field stimulation

\begin{tabular}{|c|c|c|c|c|c|}
\hline $\begin{array}{l}\text { Frequency of } \\
\text { stimulation }\end{array}$ & $\mathbf{n}$ & $\begin{array}{c}\% \text { total } t \\
\mathrm{~S}_{1}\end{array}$ & $\begin{array}{l}\text { ansmitter ove } \\
\text { ioactivity } \\
\qquad \mathrm{S}_{2}\end{array}$ & $\begin{array}{l}\text { Ratio }^{\mathrm{b}} \\
\mathrm{S}_{2} / \mathrm{S}_{1}\end{array}$ & $\begin{array}{c}\text { Spontaneous outflow } \\
\text { Ratio } \\
\mathrm{Sp}_{2} / \mathrm{Sp}_{1}\end{array}$ \\
\hline $\begin{array}{l}1 \mathrm{~Hz} \\
3 \mathrm{~Hz} \\
6 \mathrm{~Hz}\end{array}$ & $\begin{array}{l}5 \\
6 \\
5\end{array}$ & $\begin{array}{l}2.09 \pm 0.23 \\
2.63 \pm 0.29 \\
2.71 \pm 0.40\end{array}$ & $\begin{array}{l}1.97 \pm 0.23 \\
2.36 \pm 0.30 \\
2.35 \pm 0.20\end{array}$ & $\begin{array}{l}0.95 \pm 0.06 \\
0.91 \pm 0.06 \\
0.91 \pm 0.05\end{array}$ & $\begin{array}{l}0.85 \pm 0.02 \\
0.83 \pm 0.04 \\
0.79 \pm 0.01\end{array}$ \\
\hline
\end{tabular}

Calcium-dependent release was elicited twice within each experiment by electrical field stimulation ( 360 pulses, $20 \mathrm{~mA}$, $2 \mathrm{~ms}$ ) at frequencies of $1 \mathrm{~Hz}, 3 \mathrm{~Hz}$, or $6 \mathrm{~Hz}$. Evoked release of $\left[{ }^{3} \mathrm{H}\right]$-dopamine is expressed as $\%{ }^{3} \mathrm{H}$-transmitter overflow.

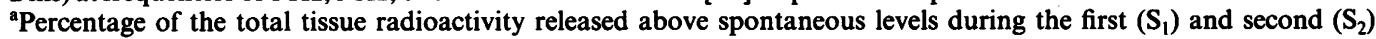
consecutive periods of field stimulation.

${ }^{b}$ Ratio of the percentage of total tissue radioactivity released by the second period of stimulation $\left(S_{2}\right)$ to that released by the first period of stimulation $\left(S_{1}\right)$.

${ }^{c}$ Ratio of the spontaneous outflow of radioactivity during the 4 min preceding the second period of stimulation $\left(\mathrm{Sp}_{2}\right)$ to that released during the 4 min preceding the first period of stimulation $\left(\mathrm{Sp}_{1}\right)$.

Shown are mean values \pm s.e.mean; $n=$ number of experiments. 

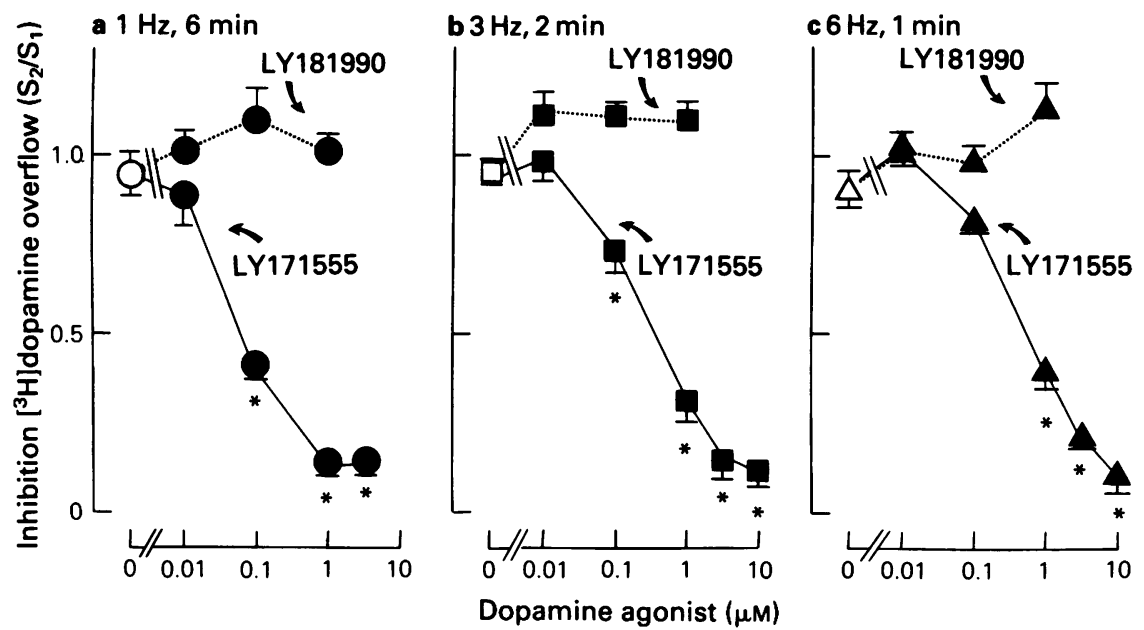

Figure 1 Effect of LY 171555 (quinpirole) and LY 181990 on the release of $\left[{ }^{3} \mathrm{H}\right]$-dopamine elicited at different frequencies of field stimulation. Ordinate scale: inhibition of $\left[{ }^{3} \mathrm{H}\right]$-dopamine overflow is the percentage of the total tissue radioactivity released above spontaneous levels, expressed as the ratio of the second $\left(S_{2}\right)$ to the first $\left(S_{1}\right)$ period of stimulation. Calcium-dependent release of $\left[{ }^{3} \mathrm{H}\right]$-dopamine was elicited twice within each experiment by field stimulation ( 360 pulses, $20 \mathrm{~mA}, 2 \mathrm{~ms}$ ) at $1 \mathrm{~Hz}$ (a), $3 \mathrm{~Hz}$ (b) or $6 \mathrm{~Hz}$ (c). Abscissa scale: micromolar concentrations of LY 171555 (quinpirole) and LY 181990 (logarithmic scale). LY 171555 and LY 181990 in the concentrations shown were added to the superfusion medium $20 \mathrm{~min}$ before the second period of stimulation $\left(\mathrm{S}_{2}\right)$ and were present for the remainder of the experiment. Control: $(O)$ at $1 \mathrm{~Hz} ;(\square)$ at $3 \mathrm{~Hz} ;(\Delta)$ at $6 \mathrm{~Hz}$. Shown are mean values of three to seven per experimental group; s.e.mean indicated by vertical lines.

$* P<0.05$ when compared with corresponding control.

released by the first period of stimulation $\left(\mathbf{S}_{2} / \mathbf{S}_{1}\right)$ did not vary significantly from unity (Table 1$)$. Omission of calcium from the superfusion medium $20 \mathrm{~min}$ before the second period of stimulation prevented the evoked release of radioactivity at all stimulation frequencies $(1 \mathrm{~Hz}, 3 \mathrm{~Hz}, 6 \mathrm{~Hz})$, but did not affect the spontaneous outflow of radioactivity.

Frequency-dependent modulation of $\left[{ }^{3} \mathrm{H}\right]$-dopamine release by the stereoisomers of LY 141865 and sulpiride

The $\mathrm{D}_{2}$-dopamine receptor agonist LY 171555 (quinpirole $\mathrm{HCl}$ ), the $(-)$-isomer of the racemate LY 141865, when added to the superfusion medium before the second period of stimulation $\left(\mathbf{S}_{2}\right)$ produced a concentration-dependent inhibition of $\left[{ }^{3} \mathrm{H}\right]-$ dopamine release (Figure 1). The maximal inhibitory effect of quinpirole was obtained at $1 \mu \mathrm{M}$ when the tissue was stimulated at $1 \mathrm{~Hz}$, and at $10 \mu \mathrm{M}$ when the tissue was stimulated at $3 \mathrm{~Hz}$ or $6 \mathrm{~Hz}$. With the number of pulses held constant (360 pulses), quinpirole $(0.01-10 \mu \mathrm{M})$ was more potent in inhibiting the evoked release of $\left[{ }^{3} \mathrm{H}\right]$-dopamine the lower the stimulation frequency, as indicated by the concentration of agonist inhibiting release by $50 \%\left(\mathrm{IC}_{50}\right)$ (Table 2$)$. The isomer of quinpirole, LY $181990(0.01-1 \mu \mathrm{M})$ when added to the superfusion medium before $S_{2}$ had no inhibitory effect on the evoked release of $\left[{ }^{3} \mathrm{H}\right]$ dopamine, regardless of concentration and stimulation frequency (Figure 1). Neither quinpirole nor LY 181990 in the range of concentrations used modified the spontaneous outflow of radioactivity.

The stereoisomers of the $D_{2}$-dopamine receptor antagonist sulpiride $(0.01-3 \mu \mathrm{M})$, when added before the second period of stimulation $\left(S_{2}\right)$, increased the evoked release of $\left[{ }^{3} \mathrm{H}\right]$-dopamine in a concentrationand frequency-dependent manner (Figure 2). R-Sulpiride was less potent than S-sulpiride at all stimulation frequencies. A maximal increase in $\left[{ }^{3} \mathrm{H}\right]$ dopamine release was obtained for S-sulpiride $(3 \mu \mathrm{M})$ when the retina tissue was stimulated at a frequency of $6 \mathrm{~Hz}$. The enhancement of $\left[{ }^{3} \mathrm{H}\right]$-dopamine release by R- or S-sulpiride was greater the higher the stimulation frequency as indicated by the concentration of antagonist increasing release by $50 \%\left(\mathrm{EC}_{150}\right)$ (Table 2). Neither stereoisomer of sulpiride in the range of concentrations used $(0.01-3 \mu \mathrm{M})$ modified the spontaneous outflow of radioactivity.

The percentage total tissue radioactivity released during the first period of stimulation $\left(S_{1}\right)$ at a frequency of $1 \mathrm{~Hz}$ (360 pulses) in the presence of the $\mathrm{D}_{2}$-dopamine receptor antagonist $\mathrm{S}$-sulpiride $(0.1 \mu \mathrm{M})$ 

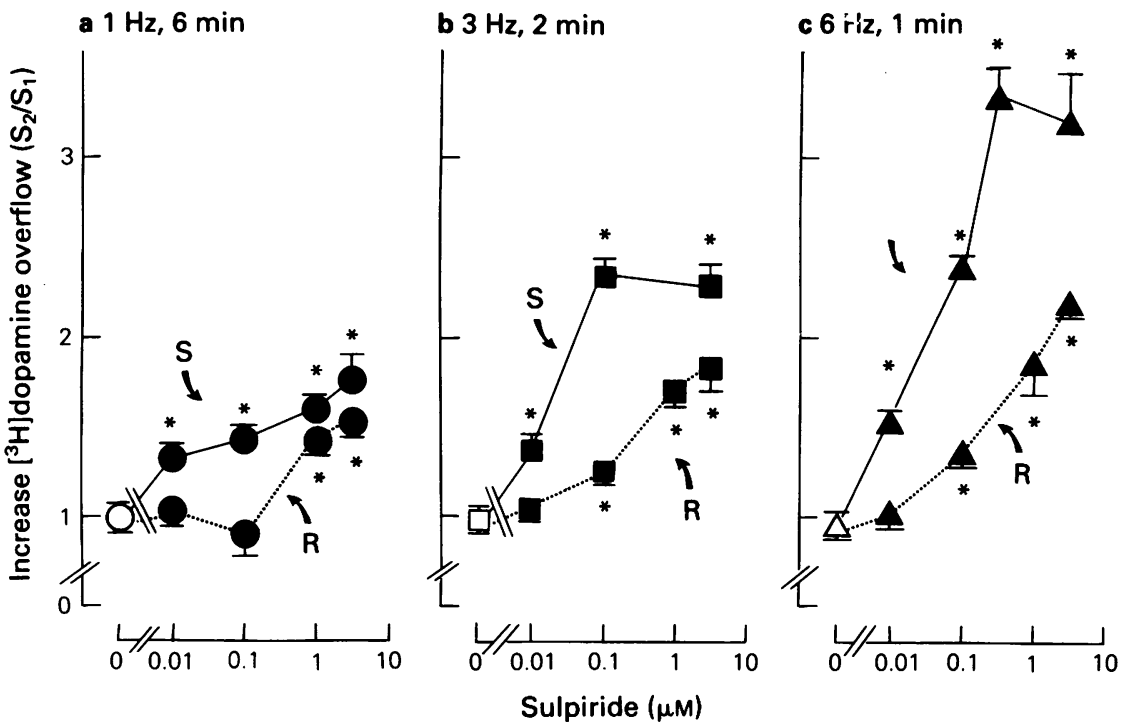

Figure 2 Effect of S- and R-sulpiride on the evoked release of $\left[{ }^{3} \mathrm{H}\right]$-dopamine elicited at different frequencies of field stimulation. Ordinate scale: increase $\left[{ }^{3} \mathrm{H}\right]$-dopamine overflow is the percentage of the total tissue radioactivity released above spontaneous levels expressed as the ratio of the second $\left(S_{2}\right)$ to the first $\left(S_{1}\right)$ period of stimulation. Calciumdependent release of $\left[{ }^{3} \mathrm{H}\right]$-dopamine was elicited twice within each experiment by field stimulation $(360$ pulses, $20 \mathrm{~mA}$, $20 \mathrm{~ms}$ ) at frequencies of $1 \mathrm{~Hz}(\mathrm{a}), 3 \mathrm{~Hz}$ (b), or $6 \mathrm{~Hz}$ (c). Abscissa scale: micromolar concentrations of S- and R-sulpiride (logarithmic scale). The dopamine antagonists S-sulpiride and R-sulpiride in the concentrations shown were added to the superfusion medium $20 \mathrm{~min}$ before the second period of stimulation $\left(\mathrm{S}_{2}\right)$ and were present for the remainder of the experiment. Control: $(O)$ at $1 \mathrm{~Hz} ;(\square)$ at $3 \mathrm{~Hz} ;(\Delta)$ at $6 \mathrm{~Hz}$. Shown are mean values of three to seven per experimental group; s.e.mean indicated by vertical lines.

${ }^{*} P<0.05$ when compared with corresponding control.

Table 2 Potency of melatonin, and the isomers of LY 141865 (LY 171555, LY 181990) and sulpiride in modifying $\left[{ }^{3} \mathrm{H}\right]$-dopamine release from rabbit retina at different frequencies of field stimulation (360 pulses)

\begin{tabular}{|c|c|c|c|c|c|}
\hline \multirow[b]{2}{*}{ Frequency of stimulation } & \multirow[b]{2}{*}{ Melatonin } & \multirow{2}{*}{$\begin{array}{l}I C_{50}(\mathrm{~nm})^{\mathrm{a}} \\
L Y 171555\end{array}$} & \multirow[b]{2}{*}{ LY 181990} & \multicolumn{2}{|c|}{$E C_{150}(\mathrm{nM})^{\mathrm{b}}$} \\
\hline & & & & S-sulpiride & $R$-sulpiride \\
\hline $1 \mathrm{~Hz}$ & 0.05 & 50 & $>1000$ & 250 & 1800 \\
\hline $3 \mathrm{~Hz}$ & 0.05 & 350 & $>1000$ & 14 & 400 \\
\hline $6 \mathrm{~Hz}$ & 0.05 & 500 & $>1000$ & 13 & 178 \\
\hline
\end{tabular}

Melatonin $(1 \mathrm{pM}-10 \mathrm{nM})$, the isomers of LY $141865(0.01-10 \mu \mathrm{M})$ and sulpiride $(0.01-3 \mu \mathrm{M})$ were added to the superfusion medium $20 \mathrm{~min}$ before the second period of stimulation $\left(\mathrm{S}_{2}\right)$ and were present for the remainder of the experiment.

${ }^{\mathrm{a}} \mathrm{IC}_{50}$ is the concentration of drug producing a $50 \%$ reduction in the release of $\left[{ }^{3} \mathrm{H}\right]$-dopamine elicited by field stimulation. The $\mathrm{IC}_{50}$ values were determined by graphical extrapolation of concentration-effect curves obtained with at least 4 concentrations of each drug.

${ }^{b} \mathrm{EC}_{150}$ is the concentration of drug producing a $50 \%$ increase in the release of $\left[{ }^{3} \mathrm{H}\right]$-dopamine elicited by field stimulation. The $\mathrm{EC}_{150}$ values were determined by graphical extrapolation of concentration-effect curves obtained with at least 4 concentrations of each drug. 

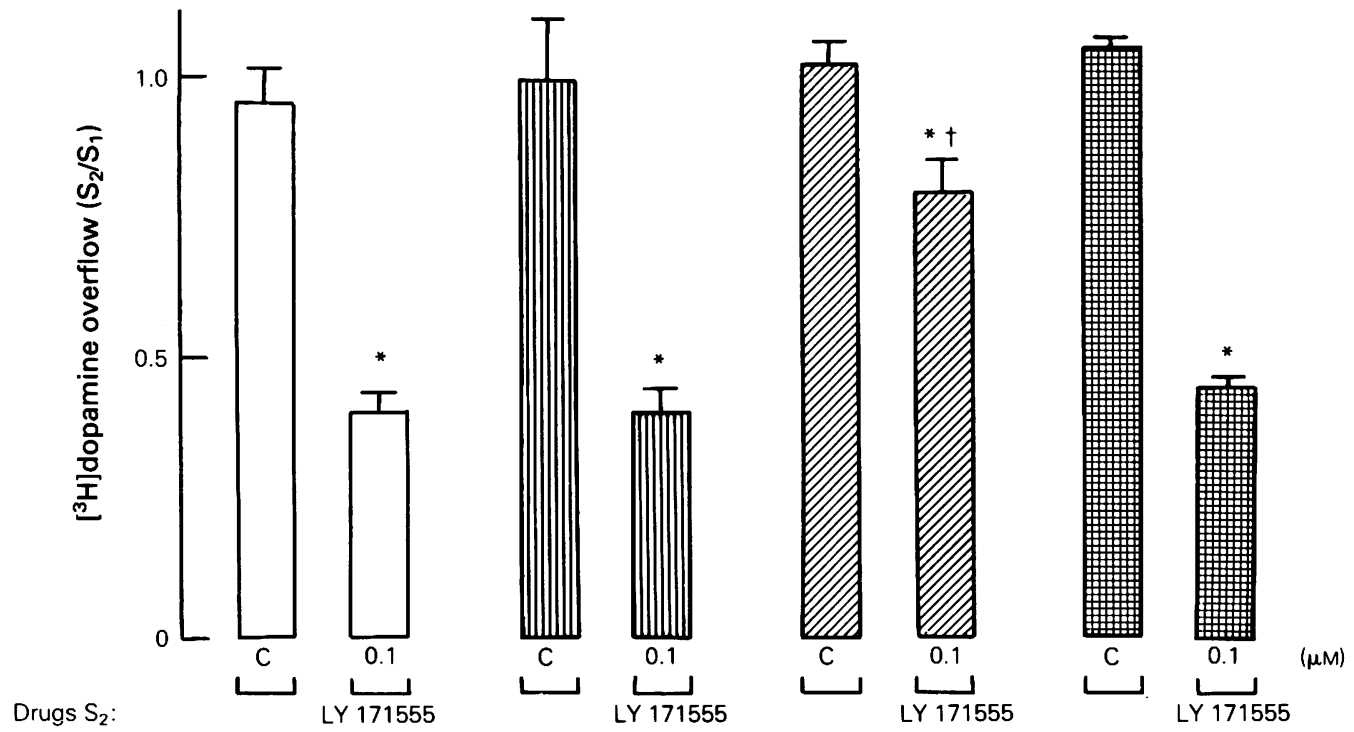

Drugs $\mathrm{S}_{1}, \mathrm{~S}_{2}$ :
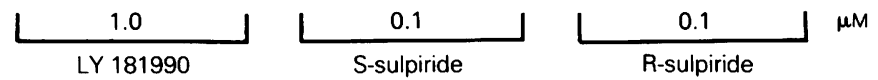

Figure 3 Antagonism of LY 171555-induced inhibition of $\left[{ }^{3} \mathrm{H}\right]$-dopamine release by LY 181990 and the isomers of sulpiride. Ordinate scale: $\left[{ }^{3} \mathrm{H}\right]$-dopamine overflow is the percentage of the total tissue radioactivity released above spontaneous levels, expressed as the ratio of the second $\left(S_{2}\right)$ to the first $\left(S_{1}\right)$ period of stimulation. Calcium-dependent release of $\left[{ }^{3} \mathrm{H}\right]$-dopamine was elicited twice within each experiment by field stimulation at $1 \mathrm{~Hz}(360$ pulses, $20 \mathrm{~mA}$, $2 \mathrm{~ms})$. Abscissa scale: micromolar concentrations of drugs used. Either LY $181990(1 \mu \mathrm{M})$, S-sulpiride $(0.1 \mu \mathrm{M})$ or Rsulpiride $(0.1 \mu \mathrm{M})$ was present in the superfusion medium from $40 \mathrm{~min}$ before $S_{1}$ until the end of the experiment. The dopamine agonist LY 171555 (quinpirole; $0.1 \mu \mathrm{M}$ ) was added to the superfusion medium 20 min before $S_{2}$. The percentage total tissue radioactivity released during the first period of stimulation $\left(S_{1}\right)$ was: for controls, $2.09 \pm 0.23 \%$ $(n=5)$; in the presence of LY $181990(1 \mu \mathrm{M}), 2.51 \pm 0.31 \%(n=9)$; in the presence of S-sulpiride $(0.1 \mu \mathrm{M})$, $3.54 \pm 0.35 \%(n=7)$; in the presence of R-sulpiride $(0.1 \mu \mathrm{M}), 3.91 \pm 0.37 \%(n=7)$. Shown are mean values of three to six per experimental group; s.e.mean shown by vertical lines.

$* P<0.05$ when compared with corresponding controls; $\dagger P<0.05$ when compared with the effect of LY 171555 alone.

was $3.54 \pm 0.35 \%(n=7)$, and in the presence of $\mathrm{R}$ sulpiride $(0.1 \mu \mathrm{M})$ was $3.91 \pm 0.37 \%(n=7)$. The ratio $\mathrm{S}_{2} / \mathrm{S}_{1}$, in the presence of $\mathrm{R}$ - or S-sulpiride did not vary significantly from the control value near unity. Under these conditions, the inhibition of $\left[{ }^{3} \mathrm{H}\right]$-dopamine release produced by the agonist quinpirole (LY 171555) was antagonized by S-sulpiride $(0.1 \mu \mathrm{M})$ (Figure 3). The effect of sulpiride was stereoselective since R-sulpiride was less potent than S-sulpiride in antagonizing the quinpirole-induced inhibition of $\left[{ }^{3} \mathrm{H}\right]$-dopamine release. LY $181990(1 \mu \mathrm{M})$ did not affect the inhibition of $\left[{ }^{3} \mathrm{H}\right]$-dopamine release produced by its isomer, quinpirole (Figure 3).

The percentage total tissue radioactivity released for $S_{1}$ at a frequency of $1 \mathrm{~Hz}(360$ pulses $)$ in the presence of the $\alpha_{2}$-adrenoceptor antagonist yohimbine $(0.1 \mu \mathrm{M})$ was $3.73 \pm 0.16 \%(n=14)$, and in the presence of the $\alpha$-receptor antagonist phentolamine $(1 \mu \mathrm{M})$ was $2.02 \pm 0.15 \%(n=19)$. The ratio $S_{2} / S_{1}$, in the presence of yohimbine or phentolamine did not vary from the control value near unity. Yohimbine $(0.1 \mu \mathrm{M})$ antagonized the inhibition of $\left[{ }^{3} \mathrm{H}\right]$-dopamine release by quinpirole, shifting the dose-effect curve to the right (Figure 4) $\left(\mathrm{IC}_{50}=251 \mathrm{nM}\right.$ for quinpirole in the presence of yohimbine $0.1 \mu \mathrm{M}$, see Table 2). The $\alpha$ receptor antagonist phentolamine $(1 \mu \mathrm{M})$ however did not antagonize the quinpirole-induced inhibition of dopamine release (Figure 4).

Effect of nomifensine on the modulation of $\left[{ }^{3} \mathrm{H}\right]-$ dopamine release by $L Y 171555$ and S-sulpiride

When the calcium-dependent release of $\left[{ }^{3} \mathrm{H}\right]-$ dopamine was elicited by field stimulation at $1 \mathrm{~Hz}$ for 


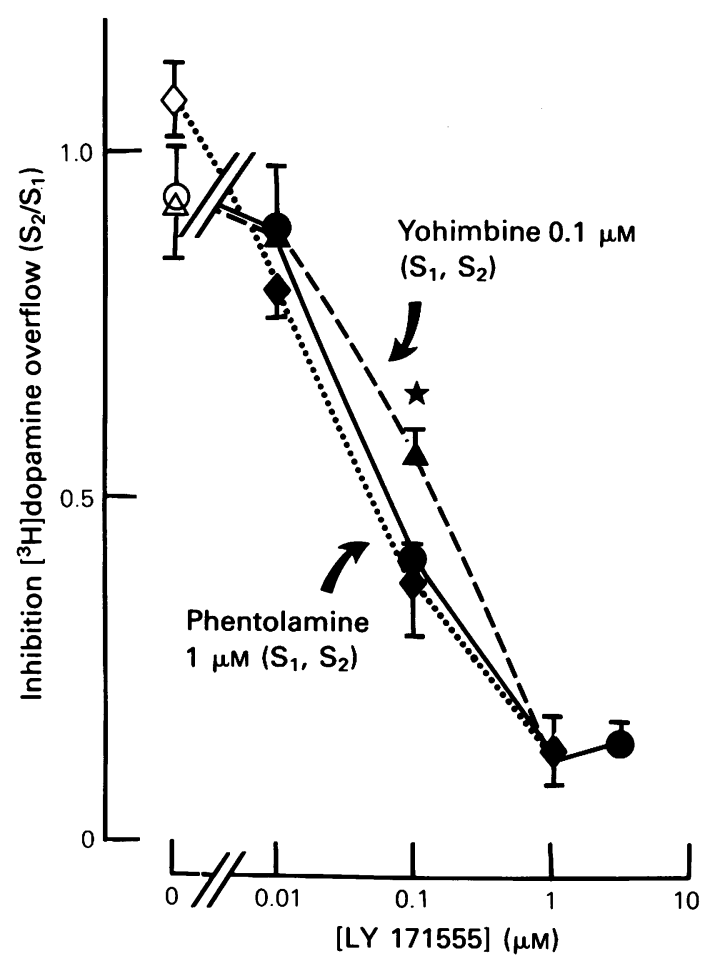

Figure 4 Effect of yohimbine and phentolamine on the inhibition of $\left[{ }^{3} \mathrm{H}\right]$-dopamine release by LY 171555 (quinpirole). Ordinate scale: inhibition $\left[{ }^{3} \mathrm{H}\right]$-dopamine overflow is the percentage of the total tissue radioactivity released above spontaneous levels, expressed as the ratio of the second $\left(S_{2}\right)$ to the first $\left(S_{1}\right)$ period of stimulation. Calcium-dependent release of $\left[{ }^{3} \mathrm{H}\right]$-dopamine was elicited twice within each experiment by field stimulation at $1 \mathrm{~Hz}$ (360 pulses, $20 \mathrm{~mA}, 2 \mathrm{~ms}$ ). Abscissa scale: micromolar concentrations of LY 171555 (logarithmic scale). LY 171555, in concentrations shown, was added to the superfusion medium 20 min before $S_{2}$. When indicated, yohimbine $(0.1 \mu \mathrm{M})$ or phentolamine $(1 \mu \mathrm{M})$ was present from 40 min before $S_{1}$ until the end of the experiment: $(O)$ control; $(O)$ LY $171555\left(S_{2}\right) ;(\Delta)$ yohimbine $\left(S_{1}, S_{2}\right) ;(\Delta)$ yohimbine $\left(S_{1}, S_{2}\right)$ plus LY $171555\left(S_{2}\right) ;(\diamond)$ phentolamine $\left(S_{1}, S_{2}\right)$; $(\diamond)$ phentolamine $\left(S_{1}, S_{2}\right)$ plus LY $171555\left(S_{2}\right)$. Shown are mean values of 3 to 7 experiments per group; s.e.mean shown by vertical lines. $* P<0.05$ when compared with control.

3 min ( 180 pulses), the percentage total tissue radioactivity released for the first period of stimulation $\left(\mathbf{S}_{1}\right)$ was $1.52 \pm 0.09 \%(n=31)$. With nomifensine $(3 \mu \mathrm{M})$ present in the superfusion medium during the first $\left(S_{1}\right)$ and second $\left(\mathbf{S}_{2}\right)$ stimulations, the percent total tissue radioactivity released for $S_{1}$ was $3.46 \pm 0.19 \%$ $(n=32)$, and the ratio $S_{2} / S_{1}$ did not vary significantly from the control value of unity. Under these experimental conditions, the potency of quinpirole
$(0.01-1 \mu \mathrm{M})$ in inhibiting the calcium-dependent release of $\left[{ }^{3} \mathrm{H}\right]$-dopamine was decreased as shown by the shift to the right in the concentration-effect curve for the $D_{2}$-dopamine receptor agonist (Figure $5 a$ ). In controls, the concentration of quinpirole inhibiting by $50 \%$ the release of $\left[{ }^{3} \mathrm{H}\right]$-dopamine $\left(\mathrm{IC}_{50}\right)$ elicited at $1 \mathrm{~Hz}$ (180 pulses) was $79 \mathrm{nM}$. In the presence of nomifensine, the $\mathrm{IC}_{50}$ value was $560 \mathrm{nM}$. In contrast, the potency of S-sulpiride $(0.01-1 \mu \mathrm{M})$ in enhancing the evoked release of $\left[{ }^{3} \mathrm{H}\right]$-dopamine was increased when nomifensine was present in the superfusion medium (Figure $5 \mathrm{~b}$ ). The concentration of S-sulpiride increasing by $50 \%$ the release of $\left[{ }^{3} \mathrm{H}\right]$-dopamine $\left(\mathrm{EC}_{150}\right)$ elicited at $1 \mathrm{~Hz}(180$ pulses) was greater than $3000 \mathrm{nM}$ in the absence of nomifensine $(3 \mu \mathrm{M})$. The $\mathrm{EC}_{150}$ value in the presence of nomifensine $(3 \mu \mathrm{M})$ was $10 \mathrm{nM}$.

\section{Inhibition of $\left[{ }^{3} \mathrm{H}\right]$-dopamine release by melatonin at different frequencies of field stimulation}

Melatonin (0.01-10 nM) inhibited the calcium-dependent release of $\left[{ }^{3} \mathrm{H}\right]$-dopamine from rabbit retina in vitro in a concentration-dependent manner (Figure 6). The maximal inhibitory effect of melatonin was obtained at a concentration of $1 \mathrm{nM}$, regardless of the frequency of stimulation applied (Figure 6). The potency of melatonin in inhibiting $\left[{ }^{3} \mathrm{H}\right]$-dopamine release was the same at stimulation frequencies of $1 \mathrm{~Hz}, 3 \mathrm{~Hz}$ and $6 \mathrm{~Hz}$ (Table 2).

\section{Discussion}

The modulation of $\left[{ }^{3} \mathrm{H}\right]$-dopamine release through activation of stereoselective $D_{2}$-dopamine autoreceptors in the rabbit retina appears to be dependent on the synaptic concentration of transmitter, altered by changes in the frequency of stimulation or by the presence of the dopamine uptake inhibitor, nomifensine. The $\mathrm{D}_{2}$-dopamine receptor agonist quinpirole (LY171555) more potently inhibited the calcium-dependent release of $\left[{ }^{3} \mathrm{H}\right]$-dopamine the lower the frequency of stimulation, while the $D_{2}$-dopamine receptor antagonist sulpiride more potently enhanced $\left[{ }^{3} \mathrm{H}\right]$ dopamine release the higher the stimulation frequency. Moreover, the potency of the agonist quinpirole was decreased in the presence of the dopamine reuptake inhibitor nomifensine, whereas the potency of the antagonist S-sulpiride was increased. In contrast, the potency of exogenous melatonin in inhibiting the evoked-release of dopamine from rabbit retina in the absence of endogenous hormone was not altered by changes in the frequency of stimulation and thus was independent of the biophase concentration of dopamine.

The inhibition of $\left[{ }^{3} \mathrm{H}\right]$-dopamine release produced 

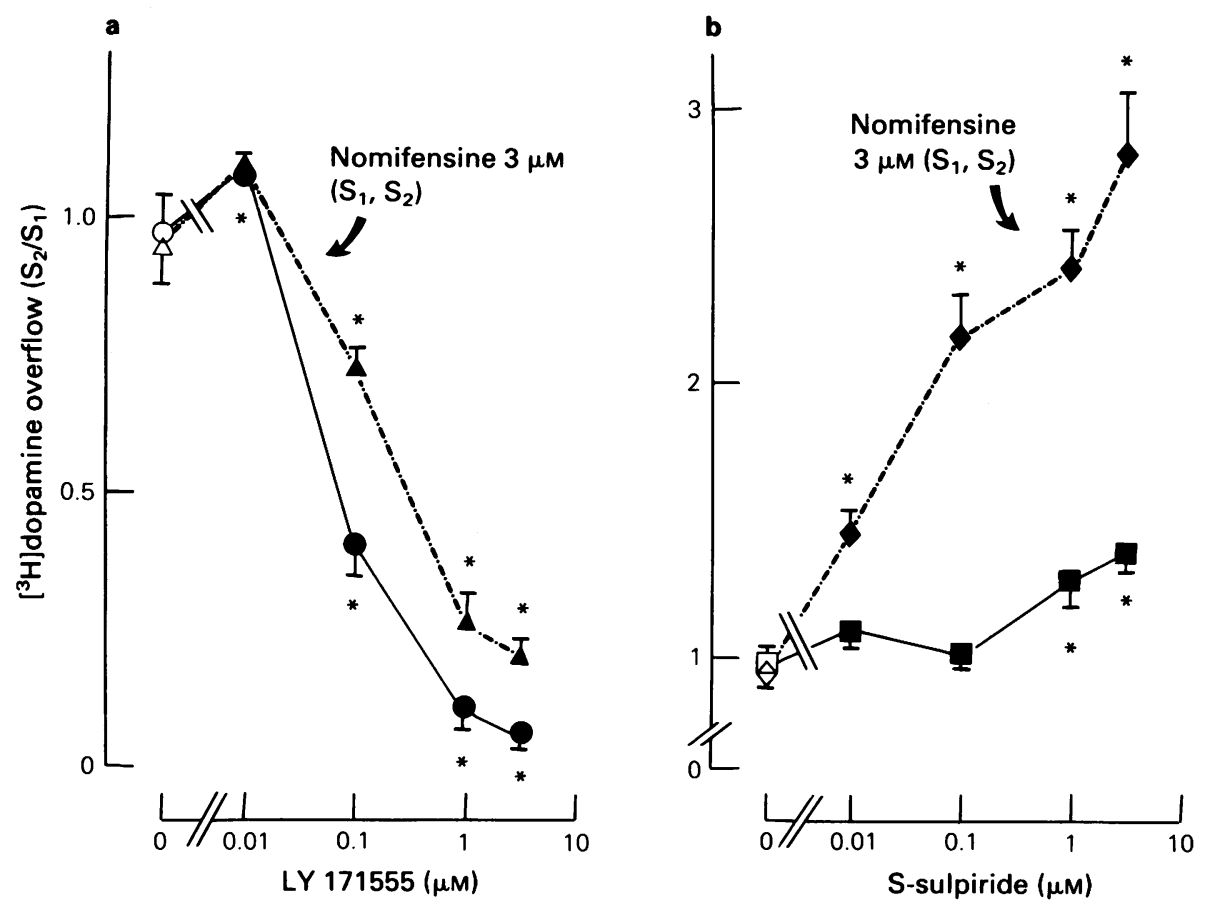

Figure 5 Effect of nomifensine on the modulation of $\left[{ }^{3} \mathrm{H}\right]$-dopamine release by LY 171555 (quinpirole) and Ssulpiride. Ordinate scale: $\left[{ }^{3} \mathrm{H}\right]$-dopamine overflow is the percentage of the total tissue radioactivity released above spontaneous levels, expressed as the ratio of the second $\left(\mathbf{S}_{2}\right)$ to the first $\left(\mathbf{S}_{1}\right)$ period of stimulation. Calcium-dependent release of $\left.{ }^{3} \mathrm{H}\right]$-dopamine was elicited twice within each experiment by a 3 min period of field stimulation at $1 \mathrm{~Hz}(180$ pulses, $20 \mathrm{~mA}, 2 \mathrm{~ms}$ ). Abscissa scale: Micromolar concentrations of (a) LY 171555 or (b) S-sulpiride (logarithmic scale). The agonist LY 171555, or the antagonist $S$-sulpiride, in concentrations shown, was added to the superfusion medium $20 \mathrm{~min}$ before $S_{2}$. Nomifensine $(3 \mu \mathrm{M})$ was present from $40 \mathrm{~min}$ before $S_{1}$ until the end of the experiment. (a) (O) Control; $(\Theta)$ LY $171555\left(S_{2}\right) ;(\Delta)$ nomifensine $\left(S_{1}, S_{2}\right) ;(\Delta)$ nomifensine $\left(S_{1}, S_{2}\right)$ plus LY $171555\left(S_{2}\right)$. (b) ( $(\square)$ Control; (ש) S-sulpiride $\left(S_{2}\right) ;(\diamond)$ nomifensine $\left(S_{1}, S_{2}\right) ;(\diamond)$ nomifensine $\left(S_{1}, S_{2}\right)$ plus S-sulpiride $\left(S_{2}\right)$. Shown are mean values of three or four experiments per group; s.e.mean shown by vertical lines.

${ }^{*} P<0.05$ when compared with corresponding control.

by the agonist quinpirole $\mathrm{HCl}$ (LY 171555) was antagonized by the isomers of the selective $D_{2^{-}}$ dopamine receptor antagonist sulpiride. The S-isomer of sulpiride was more potent than R-sulpiride at all frequencies of stimulation in its ability to enhance $\left[{ }^{3} \mathrm{H}\right]$-dopamine release. LY 181990 , the monohydrochloride salt of the dextrorotatory enantiomer of quinpirole, had no inhibitory effect on the calciumdependent release of $\left[{ }^{3} \mathrm{H}\right]$-dopamine and did not modify the quinpirole-induced inhibition of $\left[{ }^{3} \mathrm{H}\right]-$ dopamine release. These results are consistent with the regulation of dopamine release from rabbit retina in vitro through stereoselective $\mathrm{D}_{2}$-dopamine autoreceptors (Dubocovich \& Weiner, 1981; 1985). The modulation of dopamine release by stereoselective presynaptic $D_{2}$-dopamine autoreceptors is well established in the striatum (Arbilla \& Langer, 1981; Starke et al., 1983).
In the rabbit retina, quinpirole inhibited the calcium-dependent release of $\left[{ }^{3} \mathrm{H}\right]$-dopamine evoked by field stimulation at frequencies of $1 \mathrm{~Hz}, 3 \mathrm{~Hz}, 6 \mathrm{~Hz}$ with $\mathrm{IC}_{50}$ values in the nanomolar range, consistent with the action of the agonist at dopamine autoreceptors of $D_{2}$-subtype (Kebabian \& Calne, 1979; Stoof \& Kebabian, 1984; Dubocovich \& Weiner, 1985). Quinpirole has been shown to have $\alpha_{2}$-adrenoceptor agonist activity at concentrations of 0.1 to $100 \mu \mathrm{M}$ (Cohen et al., 1984). Although the calcium-dependent release of $\left[{ }^{3} \mathrm{H}\right]$-dopamine from rabbit retina in vitro is modulated by inhibitory $\alpha_{2}$-adrenoceptors (Dubocovich, 1984), the lack of antagonism of the quinpirole-induced inhibition of $\left[{ }^{3} \mathrm{H}\right]$-dopamine release by the $\alpha$-receptor antagonist phentolamine suggests that at concentrations up to $1 \mu \mathrm{M}$, quinpirole did not activate $\alpha_{2}-$ receptors. The $\alpha_{2}$-antagonist yohimbine however did modify the inhibition of dopamine release by quin- 


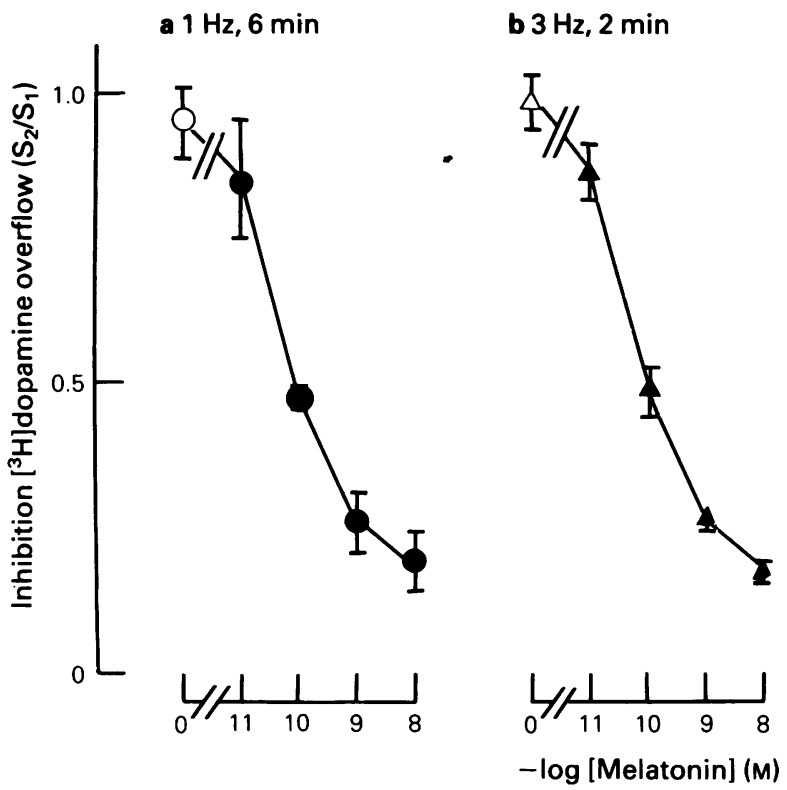

c $6 \mathrm{~Hz}, 1 \mathrm{~min}$

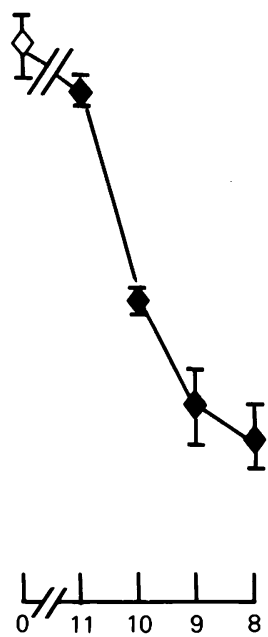

Figure 6 Inhibition of $\left[{ }^{3} \mathrm{H}\right]$-dopamine release by melatonin at different frequencies of field stimulation. Ordinate scale: inhibition of $\left[{ }^{3} \mathrm{H}\right]$-dopamine overflow is the percentage of the total tissue radioactivity released above spontaneous levels, expressed as the ratio of the second $\left(S_{2}\right)$ to the first $\left(S_{1}\right)$ period of stimulation. Calcium-dependent release of $\left[{ }^{3} \mathrm{H}\right]-$ dopamine was elicited twice within each experiment by field stimulation ( 360 pulses, $20 \mathrm{~mA}, 2 \mathrm{~ms}$ ) at frequencies of $1 \mathrm{~Hz}$ (a), $3 \mathrm{~Hz}$ (b), or $6 \mathrm{~Hz}$ (c). Abscissa scale: molar concentrations of melatonin (logarithmic scale). Melatonin, in the concentration shown, was added to the superfusion medium 20 min before $S_{2}$ and remained present for the duration of the experiment. Controls: $(O) 1 \mathrm{~Hz} ;(\Delta) 3 \mathrm{~Hz} ;(\diamond) 6 \mathrm{~Hz}$. Shown are the mean values of three to twenty-six per experimental group; s.e.mean shown by vertical lines.

pirole, shifting the dose-effect curve to the right. This antagonism by yohimbine of the inhibitory effect of quinpirole can be explained by the $\mathrm{D}_{2}$-dopamine receptor blocking action of yohimbine (Scatton et al., 1980).

The potencies of dopamine receptor agonists and antagonists in modulating dopamine release at different frequencies of field stimulation through autoreceptor activation appears to be related to changes in the synaptic concentration of neurotransmitter. The total tissue radioactivity released by the first period of field stimulation $\left(S_{1}\right)$ was of similar magnitude at frequencies of 1,3 and $6 \mathrm{~Hz}$ (360 pulses). However, the higher the frequency of stimulation the greater the concentration of dopamine in the synaptic gap per unit of time. Moreover, with increasing frequency of stimulation the formation of metabolities declines, possibly due to the reduction of neuronal reuptake of transmitter under conditions of depolarization (Holtz \& Coyle, 1974; Dubocovich \& Langer, 1976). Frequency-dependent modulation of transmitter release by respective agonists and antagonists through activation of presynaptic autoreceptors has also been demonstrated for dopamine and acetylcholine in the rabbit striatum (Cubeddu \& Hoffmann, 1983; James \& Cubeddu, 1984). Similarly, the effects of $\alpha$-receptor agonists and antagonists on noradrenaline release from cortical slices (Reichenbacher et al., 1982; Heepe \& Starke, 1985) and from sympathetic nerve terminals in the periphery (Limberger \& Starke, 1984) largely depend on the parameters of stimulation employed.

The spontaneous outflow of radioactivity from rabbit retina labelled in vitro with $\left[{ }^{3} \mathrm{H}\right]$-dopamine consists mainly of $\left[{ }^{3} \mathrm{H}\right]$-dopamine metabolites (Dubocovich \& Weiner, 1981). Unmetabolized $\left[{ }^{3} \mathrm{H}\right]-$ dopamine however, accounts for about $50 \%$ of the release of tritium above the spontaneous levels elicited by the period of electrical field stimulation from rabbit retina (Dubocovich \& Weiner, 1981). In order to determine further whether the potencies of quinpirole and sulpiride in modifying the evoked release of $\left[{ }^{3} \mathrm{H}\right]-$ dopamine from rabbit retina were dependent upon the synaptic concentration of dopamine released, experiments were done in the presence of the dopamine uptake inhibitor nomifensine (Hyttel, 1978). By inhibiting the reuptake of released dopamine, nomifensine acts to increase the synaptic concentration of the 
transmitter, an effect equivalent to an increase in stimulation frequency (Zumstein et al., 1981). In the experiments carried out in the presence of nomifensine, the conditions of field stimulation $(1 \mathrm{~Hz}, 180$ pulses) were modified to obtain ${ }^{3} \mathrm{H}$-overflow of similar magnitude to controls. Nomifensine decreased the potency of the agonist quinpirole. In contrast, the antagonist S-sulpiride was more potent in the presence of the uptake inhibitor. The results are compatible with an increase in the synaptic concentration of dopamine following neuronal uptake inhibition by nomifensine and a consequent increase in $D_{2}$ dopamine receptor activation. Thus, the modulation of dopamine release from rabbit retina through activation of $\mathrm{D}_{2}$-dopamine autoreceptors appears to be dependent on the concentration of dopamine in the synapse.

The effect of stimulation frequency on presynaptic receptor modulation of dopamine release in the absence of endogenous ligand was investigated by determining the potency of exogenous melatonin in inhibiting dopamine release at different frequencies of stimulation. The levels of immunoreactive melatonin in the rabbit retina display a diurnal rhythm and are low or undetectable during the light period when the in vitro release experiments described here were performed (Dubocovich et al., 1985). Under these experimental conditions, frequency-dependent changes in the synaptic concentration of dopamine had no effect on the inhibitory potency of exogenous melatonin.

In the rabbit retina, melatonin inhibited the release of dopamine evoked by field stimulation with the same potency regardless of stimulation frequency, when the number of pulses was kept constant. Since the percentage total tissue radioactivity released by the first period of stimulation $\left(\mathbf{S}_{1}\right)$ and the inhibitory effect of melatonin were unaffected by the frequency of stimulation employed, we conclude that field stimulation delivered at frequencies of $1 \mathrm{~Hz}, 3 \mathrm{~Hz}$, and $6 \mathrm{~Hz}$

\section{References}

ARBILLA, S. \& LANGER, S.Z. (1981). Stereoselectivity of presynaptic autoreceptors modulating dopamine release. Eur. J. Pharmac., 76, 345-351.

BAUMANN, P.A. \& KOELLA, W.P. (1980). Feed back control of noradrenaline release as a function of noradrenaline concentration in the synaptic cleft in cortical slices of the rat. Brain Res., 189, 437-448.

COHEN, M.L., SHAAR, C.J. \& COLBERT, W.E. (1984). Alpha-2 agonist activity of dopamine $\mathrm{DA}_{2}$-agonist LY 171555. $\mathrm{J}$. cardiovasc. Pharmac., 6, 1245-1248.

CUBEDDU, L.X. \& HOFFMANN, I.S. (1983). Frequencydependent release of acetylcholine and dopamine from rabbit striatum: Its modulation by dopaminergic receptors. J. Neurochem., 41, 94-101.

DUBOCOVICH, M.L. (1983). Melatonin is a potent modulator of dopamine release in the retina. Nature, 306, 782-784.
( 360 pulses) resulted in the same amount of calcium entry into the terminal. In the rat hypothalamus, the inhibition of dopamine release by melatonin appears to involve a reduction of calcium entry into the presynaptic nerve ending, as melatonin reduces tissue uptake of ${ }^{45} \mathrm{Ca}^{2+}$ during field stimulation or potassium depolarization (Zisapel \& Laudon, 1983). Moreover, we have found that the inhibitory effect of melatonin on the release of $\left[{ }^{3} \mathrm{H}\right]$-dopamine from rabbit retina evoked by field stimulation $(20 \mathrm{~mA}, 2 \mathrm{~ms})$ at frequencies of $1 \mathrm{~Hz}, 3 \mathrm{~Hz}$ or $6 \mathrm{~Hz}$, was potentiated when the number of pulses was lowered from 360 to 180 pulses and when the calcium concentration in the superfusion medium was reduced from $1.3 \mathrm{mM}$ to $0.65 \mathrm{mM}$ (Dubocovich \& Hensler, 1985b). These results are compatible with the hypothesis that activation of the melatonin receptor may inhibit dopamine release from rabbit retina by reducing the availability of calcium for the stimulus-secretory process.

Melatonin is approximately 1000 times more potent than dopamine and $\mathrm{D}_{2}$-dopamine receptor agonists (i.e. quinpirole) in inhibiting dopamine release from rabbit retina (Dubocovich, 1983). The difference in the potencies of dopamine agonists and melatonin in inhibiting dopamine release from retina suggests that in vivo, endogenous melatonin may be the more important modulator of dopamine release during the dark period (Dubocovich et al., 1985). Conversely, during the light period when melatonin levels in the retina are very low, modulation of dopamine release may be primarily mediated through the activation of $\mathrm{D}_{2}$-autoreceptors.

This work was supported by USPHS Grant EY 04788 to M.L.D. and by NRSA Fellowship MH 09215 to J.G.H. The authors would like to thank Patrick H. Rita for excellent technical assistance, and Janet Henderson for typing the manuscript.
DUBOCOVICH, M.L. (1984). Alpha-2 adrenoceptors modulate $\left[{ }^{3} \mathrm{H}\right]$-dopamine release from rabbit retina. $J$. Pharmac. exp. Ther., 230, 149-156.

DUBOCOVICH, M.L. (1985). Characterization of a retinal melatonin receptor. J. Pharmac. exp. Ther., 234, 395-401.

DUBOCOVICH, M.L. \& HENSLER, J.G. (1985a). Modulation of dopamine release at different frequencies of stimulation from rabbit retina by a D-2 dopamine agonist and melatonin. Br. J. Pharmac., 85, 240P.

DUBOCOVICH, M.L. \& HENSLER, J.G. (1985b). Effects of calcium concentration on the melatonin-induced inhibition of $\left[{ }^{3} \mathrm{H}\right]$-dopamine release from rabbit retina. Soc. Neurosci. Abstr., 11, 500.

DUBOCOVICH, M.L. \& LANGER, S.Z. (1976). Influence of the frequency of nerve stimulation on the metabolism of $\left[{ }^{3} \mathrm{H}\right]-$ norepinephrine released from the perfused cat spleen: 
Differences observed during and after stimulation. $J$. Pharmac. exp. Ther., 198, 83-101.

DUBOCOVICH, M.L., LUCAS, R.C. \& TAKAHASHI, J.S. (1985). Light-dependent regulation of dopamine receptors in mammalian retina. Brain Res., 335, 321-325.

DUBCOVICH, M.L. \& WEINER, N. (1981). Modulation of the stimulation-evoked release of $\left[{ }^{3} \mathrm{H}\right]$-dopamine in the rabbit retina. J. Pharmac. exp. Ther., 219, 701-707.

DUBOCOVICH, M.L. \& WEINER, N. (1983). Enkephalins modulate $\left[{ }^{3} \mathrm{H}\right]$-dopamine release from rabbit retina in vitro. J. Pharmac. exp. Ther., 224, 634-639.

DUBOCOVICH, M.L. \& WEINER, N. (1985). Pharmacological differences between the D-2 autoreceptor and the D-1 dopamine receptor in rabbit retina. J. Pharmac. exp. Ther., 233, 747-754.

FULLER, R.W. \& HEMRICK-LUECKE, S.K. (1985). Decrease in hypothalamic epinephrine concentration and other neurochemical changes produced by quinpirole, a dopamine agonist, in rats. J. neural Transmission, 61, $161-173$.

HEEPE, P. \& STARKE, K. (1985). Alpha-adrenoceptor antagonists and the release of noradrenaline in rabbit cerebral cortex slices: support for the alpha-autoreceptor hypothesis. Br. J. Pharmac., 84, 147-155.

HOLTZ, R.W. \& COYLE, J.T. (1974). The effects of various salts, temperature and the alkaloids veratridine and batrachotoxin on the uptake of $\left[{ }^{3} \mathrm{H}\right]$-dopamine into synaptosomes from rat striatum. Molec. Pharmac., 10, 746-758.

HYTTEL, J. (1978). Inhibition of $\left[{ }^{3} \mathrm{H}\right]$-dopamine accumulation in rat striatal synaptosomes by psychotropic drugs. Biochem. Pharmac., 27, 1063-1068.

JAMES, M.K. \& CUBEDDU, L.X. (1984). Frequency-dependent muscarinic receptor modulation of acetylcholine and dopamine release from rabbit striatum. J. Pharmac. exp. Ther., 229, 98-104.

KEBABIAN, J.W. \& CALNE, D.B. (1979). Multiple receptors for dopamine. Nature, 277, 93-96.

LEHMANN, J., BRILEY, M. \& LANGER, S.Z. (1983). Characterization of dopamine autoreceptor and $\left[{ }^{3} \mathrm{H}\right]$-spiperone binding sites in vitro with classical and novel dopamine receptor agonists. Eur. J. Pharmac., 88, 11-26.

LIMBERGER, N. \& STARKE, K. (1984). Further study of prerequisites for the enhancement by alpha-adrenoceptor antagonists of the release of noradrenaline. Naunyn-
Schmiedebergs Arch. Pharmac., 325, 240-246.

REICHENBACHER, D., REIMANN, W. \& STARKE, K. (1982). Alpha-adrenoceptor-mediated inhibition of noradrenaline release in rabbit brain cortex slices. Receptor properties and role of the biophase concentration of noradrenaline. Naunyn-Schmiedebergs Arch. Pharmac., 319, $71-77$.

SCATTON, B., ZIVKOVIC, B. \& DEDEK, J. (1980). Antidopaminergic properties of yohimbine. J. Pharmac. exp. Ther., 215, 494-499.

STARKE, K., SPATH, L., LANG, J.D. \& ADELUNG, C. (1983). Further functional in vitro comparison of pre- and postsynaptic dopamine receptors in the rabbit caudate nucleus. Naunyn-Schmiedebergs Arch. Pharmac., 323, 298-306.

STOOF, J.C. \& KEBABIAN, J.W. (1984). Two dopamine receptors: Biochemistry physiology and pharmacology. Life Sci., 35, 2281-2296.

TITUS, R.D., KORNFIELD, E.C., JONES, N.D., CLEMENS, J.A., SMALSTIG, E.B., FULLER, R.W., HAHN, R.A., HYNES, M.D., MASON, N.R., WONG, D.T. \& FOREMAN, M.M. (1983). Resolution and absolute configuration of an ergoline-related dopamine agonist, trans-4, 4a,5,6,7,8,8a, 9-octahydro-5-propyl-1H (or 2H)-pyrazolo [3,4-g] quinoline. J. med. Chem., 26, 1112-1116.

TSURUTA, K., FREY, E.A., GREWE, C.W., COTE, .T.E., ESKAY, R.L. \& KEBABIAN, J.W. (1981). Evidence that LY 141865 specifically stimulates the D-2 dopamine receptor. Nature, 292, 463-465.

WONG, D.T., BYMASTER, F.P., REID, L.R., FULLER, R.W., PERRY, K.W. \& KORNFIELD, E.C. (1983). Effect of a stereoselective D-2-dopamine agonist on acetylcholine concentration in corpus striatum of rat brain. $J$. neural Transmission, 58, 55-67.

ZISAPEL, N. \& LAUDON, M. (1983). Inhibition by melatonin of dopamine release from rat hypothalamus: regulation of calcium entry. Brain Res., 272, 378-381.

ZUMSTEIN, A., KARDUCK, W. \& STARKE, K. (1981). Pathways of dopamine metabolism in the rabbit caudate nucleus in vitro. Naunyn-Schmiedebergs Arch. Pharmac., 316, 205-217.

(Received August 14, 1985. Revised January 2, 1986. Accepted January 6, 1986.) 